\title{
Influence of multiple- and single-species infestations on herbivore-induced cotton volatiles and Anthonomus grandis behaviour
}

\author{
Diego Martins Magalhães ${ }^{1,2} \cdot$ Miguel Borges $^{2} \cdot$ Raúl Alberto Laumann $^{2} \cdot$ Maria Carolina Blassioli Moraes $^{2} \mathbb{C}$
}

Received: 2 May 2017 / Revised: 7 February 2018 / Accepted: 15 March 2018 / Published online: 20 March 2018

(c) Springer-Verlag GmbH Germany, part of Springer Nature 2018

\begin{abstract}
Plants interact with multiple organisms throughout their life cycle. As a result, they are commonly attacked by multiple species of herbivores, leading to the induction of plant defence systems. Herbivore-induced plant volatiles (HIPVs) play an important role in the interaction between community members and can be used to manipulate insect pest behaviour, being a valuable tool in integrated pest management strategy. In this study, the interaction of two chewing insects, the boll weevil, Anthonomus grandis, and the fall armyworm, Spodoptera frugiperda, and of one piercing-sucking insect, the Neotropical brown stinkbug, Euschistus heros, was evaluated for the induction of volatile compounds in cotton under single- and multiple-species attacks. As a control, the emissions of undamaged plants were also measured. In addition, the effect of HIPVs on boll weevil behaviour was also assessed. Qualitatively, single- and multiple-species herbivory induced a similar volatile blend. There was, however, a difference in the amount and proportion of compounds emitted. Plants infested with $E$. heros emitted a blend of volatiles more similar to that of the undamaged control compared to the other herbivore-induced treatments. The plant volatiles emitted due to simultaneous multiple-species herbivory were induced faster than volatiles emitted by sequential herbivory events, indicating different induction mechanisms depending on the attack configuration. In addition, cotton volatiles induced by an individual attack of $A$. grandis were attractive to conspecifics, as were the volatiles induced by multiple-species herbivory in both simultaneous and sequential attacks. The use of cotton HIPVs, both under multiple- and single-species attack, can be used for the development of alternative methods for semiochemical-based weevil management, e.g., enrichment of aggregation pheromone traps with plant volatiles.
\end{abstract}

Keywords Boll weevil $\cdot$ Euschistus heros $\cdot$ Semiochemicals $\cdot$ Spodoptera frugiperda $\cdot$ Y-tube olfactometer

\section{Key message}

- Single- and multiple-species herbivory induced qualitatively similar but quantitatively different volatile blends in cotton. The order of herbivores attack is an important feature regulating cotton plants volatile emission.

Communicated by I. Hiltpold.

Maria Carolina Blassioli Moraes

carolina.blassioli@embrapa.br

1 Department of Zoology, Institute of Biological Sciences, University of Brasília, 70910-900 Brasília, DF, Brazil

2 EMBRAPA Genetic Resources and Biotechnology, CEP 70770-917 Brasília, DF, Brazil
- Anthonomus grandis presents positive chemotaxis to herbivore-induced volatiles when conspecifics are present in the plant in both single- and multiple-species herbivory, thus being able to recognize the presence of conspecifics even when heterospecifics are also present in cotton plants.

- Herbivore-induced cotton volatiles can be applied in semiochemical-based A. grandis management.

\section{Introduction}

In agroecosystems and natural environments, plants are part of diverse, complex communities, interacting with numerous organisms both positively and negatively. Plants have therefore developed sophisticated defence strategies that allow them to respond to attacks from herbivores and pathogens 
in a specific way (Dicke et al. 2009; Thaler et al. 2012; Stam et al. 2014). Volatiles emitted by plants, as defence mechanisms, can directly repel or intoxicate herbivores (direct defence) or attract natural enemies (indirect defence) (Dudareva et al. 2006). One of the most studied forms of chemical defence is the emission of herbivore-induced plant volatiles (HIPVs). HIPVs are highly diverse and are involved in important ecological interactions including insect-plant, pathogen-plant, insect-pathogen-plant and plant-plant interactions (Dicke et al. 2009; Ponzio et al. 2013). When herbivores feed on plants, their oral secretions and the damage itself provide the initial signal that elicits the release of HIPVs from the site of injury (Paré and Tumlinson 1997). However, the emission of these chemicals is not restricted to the site of injury; systemic responses can also be expressed (Turlings and Tumlinson 1992; Röse et al. 1996; Röse and Tumlinson 2005).

HIPVs primarily comprise terpenoids and fatty acid derivatives, mostly green leaf volatiles (GLVs) (Arimura et al. 2009). GLVs are usually released soon after herbivoreinflicted injury, while terpenoids are released a few hours after infestation due to the de novo synthesis of many compounds (Paré and Tumlinson 1997; Dudareva et al. 2006). One of the multiple functions of HIPVs is to defend plants against herbivores, either through toxic, repellent or deterrent properties, or by attracting the natural enemies of the attacking herbivores (Dudareva et al. 2006). Plants response depends on the level of induction and their indirect defence on the abilities of the natural enemies to discriminate the emitted odours. These responses can be considered adaptive since they lead to reduced herbivore density (Dicke 1995).

Most studies on HIPVs emission have focused on the effects of these volatiles on the behaviour of the third trophic level, showing a positive effect for the plant by attracting the herbivore's natural enemies (Turlings et al. 1990; de Moraes et al. 1998; Moraes et al. 2011; Michereff et al. 2013). Increased volatiles production due to herbivore damage can, however, distinguish plants from neighbours, introducing risk since herbivores also use these compounds for food localization (Dudareva et al. 2006; Szendrei et al. 2009; Addesso et al. 2011; Magalhães et al. 2012; Silva et al. 2015).

Herbivore damage type is another factor that directly influences the composition of HIPVs. Plants present two major response channels regulated by the phytohormones jasmonate and salicylate, which are involved in the foremost defence system against attackers (Thaler et al. 2002). The jasmonic acid (JA) pathway is especially activated in response to chewingbiting herbivores, while the salicylic acid (SA) pathway is turned on when plants are attacked by piercing-sucking herbivores (Bostock et al. 2001). Many studies have investigated HIPVs emissions in a single insect-plant system, oversimplifying the trophic interactions mediated by plant volatiles. In nature, plants interact with multiple organisms simultaneously both above and belowground (Rasmann and Turlings 2007; Soler et al. 2012). In the context of a multiple-species attack, especially in the case of insects from different feeding guilds, plants can prioritize one metabolic pathway over another, influencing the expression of the defence (Ponzio et al. 2013). Therefore, the order of herbivore attack is important, because the first attackers may trigger a plant response, which in turn may compromise its defence against the second attacker (Bruinsma and Dicke 2008; Poelman et al. 2008). Multiple-species attack then induces phenotypic changes that increase the complexity of these systems. The effect of multiple-species attack is difficult to predict and can be extremely variable (Rodriguez-Saona et al. 2003; Ponzio et al. 2016). In cotton, simultaneous herbivory inflicted by insects from different guilds usually causes an increase or decrease in the emission of some volatile compounds, compared to single-species damage. The general chemical profile is, however, quite similar in both situations (Rodriguez-Saona et al. 2003).

In a previous study, it was found that cotton plants individually damaged by the Neotropical brown stinkbug Euschistus heros Fabricius (Hemiptera: Pentatomidae), the fall armyworm Spodoptera frugiperda JE Smith (Lepidoptera: Noctuidae) and the boll weevil Anthonomus grandis Boh. (Coleoptera: Curculionidae) presented different quantitative volatile profiles, even though no qualitative differences were observed (Magalhães et al. 2012). Moreover, HIPVs from individual attacks of $E$. heros and S. frugiperda did not elicit movement towards these volatile sources in the boll weevil, which was only attracted by HIPVs from conspecifics attack (Magalhães et al. 2012; Silva et al. 2015). The objective of this study was to investigate the effect of simultaneous and sequential multiple-species attack of E. heros, S. frugiperda and A. grandis in the cotton cultivar Delta Opal, comparing it to the individual induction profile of each of these insects. The effect of these volatiles on the chemotaxis of $A$. grandis was also evaluated. Specifically, it was aimed to evaluate whether (1) the volatile profile of cotton with single-species herbivory differs from that of multiple-species herbivory; and (2) HIPVs from the multiple-species attack attract the boll weevil in a Y-tube olfactometer. The evaluation of cotton HIPVs on A. grandis behaviour would facilitate the understanding of boll weevil-cotton plant interactions and the development of alternative methods for semiochemical-based weevil management, e.g., enrichment of aggregation pheromone traps with plant volatiles.

\section{Materials and methods}

\section{Insect rearing}

Anthonomus grandis were reared in plastic containers on an artificial diet (a mixture of agar, beer yeast, wheat germ, 
soy protein, glucose, ascorbic and sorbic acid, Nipagin flour from embryo cottonseed (Pharmamedia ${ }^{\circledR}$, Traders Protein, USA), Wesson salt mixture, Vanderzant's vitamin and water; Schmidt et al. 2001) under controlled conditions $\left(25 \pm 1{ }^{\circ} \mathrm{C}\right.$, $60 \pm 10 \% \mathrm{RH}$, and 14:10 L:D). Newly moulted adults were sexed using the tergal-notch method (Sappington and Spurgeon 2000), transferred to $250 \mathrm{~mL}$ plastic cages (15 insects/ cage) and fed with the artificial diet. Food and water were changed three times per week. To prevent interactions between sexes, males were kept in cages separated from females after the imaginal moult. Virgin 10-day-old male and female weevils were used in all experiments. Euschistus heros were reared in plastic containers as described by Silva et al. (2008), on a diet of soybeans (Glycine max L.), sunflower seeds (Helianthus annuus L.), raw peanuts (Arachis hypogaea L.), fresh green beans (Phaseolus vulgaris L.), and water, maintained at $26 \pm 1{ }^{\circ} \mathrm{C}$ and $65 \pm 10 \% \mathrm{RH}$ and under a photoperiod of 14:10 L/D. The food supply was renewed twice a week. To obtain virgin females, the insects were sexed after their imaginal moult and cuticle hardening. In the experiments, virgin 15-day-old females were used. Spodoptera frugiperda larvae were reared in plastic containers on an artificial diet based on beans (P. vulgaris), maintained at $26 \pm 1{ }^{\circ} \mathrm{C}$ and $65 \pm 10 \% \mathrm{RH}$ and under a photoperiod of 14:10 L:D (Schmidt et al. 2001). Third-instar larvae were used in the experiments.

\section{Plants}

Gossypium hirsutum L. (var. Delta Opal) were grown individually in $1.5-\mathrm{L}$ pots filled with soil and an organic substrate (in a proportion of 1:1). Plants were grown in a greenhouse under controlled conditions $\left(27 \pm 1{ }^{\circ} \mathrm{C}\right.$ and $14: 10$ $\mathrm{L}: \mathrm{D})$. Cotton plants used in the experiments were 12 weeks old at the reproductive stage (presence of squares).

\section{Induced plant volatiles}

Cotton plants were randomly assigned to the following treatments: undamaged control plants (UD), single-species herbivory and two multiple-species herbivory settings, one with simultaneous feeding damage and the other with sequential feeding damage. The single-species herbivory consisted of cotton damaged by two adult female $A$. grandis (AGD). Female boll weevils were used to avoid the production of pheromone, as only males produce it. In the simultaneous feeding treatment (MHD-Sim), two adult female A. grandis + two adult female E. heros + two third-instar S. frugiperda larvae were allowed to feed on the same plant at the same time. In the sequential feeding treatment (MHD-Seq) the same number of insects as in the previous treatment were added to the plant, but $E$. heros was released first; only after $72 \mathrm{~h}$ of feeding, the A. grandis and S. frugiperda larvae were added. Stinkbugs were placed first because previous studies showed that cotton and soybean plants take from 72 to $96 \mathrm{~h}$ to start the production of HIPVs in response to piercingsucking insects attack (Michereff et al. 2013; Magalhães et al. 2012). Both chewing insects start the induction of volatiles in the first $24 \mathrm{~h}$ in cotton (Magalhães et al. 2012). All insects were starved for $24 \mathrm{~h}$ prior the experiment to stimulate immediate feeding. Data from E. heros (EHD) and $S$. frugiperda (SFD) single-species herbivory were obtained from previously experiments under similar conditions as described.

\section{Air entrainment of plants}

Cotton plants were placed individually in cylindrical glass chambers (internal volume $10 \mathrm{~L}$ ). The plastic pots and soil were covered with aluminium foil to reduce collection of volatiles from these sources. Twelve independent chambers were run simultaneously. Charcoal-filtered air was pumped in at $1.0 \mathrm{~L} \mathrm{~min}^{-1}$ and drawn out at $0.6 \mathrm{~L} \mathrm{~min}^{-1}$ through an adsorbent, Porapak Q tube (60 mg, 80-100 mesh, Supelco, PA, USA), connected to the system via PTFE tubing. The difference in flow created a slight positive pressure to ensure that unfiltered air did not enter the system. Cotton plant volatiles were collected for $24 \mathrm{~h}$ over four consecutive days, and the adsorbent tubes were eluted with $0.5 \mathrm{~mL}$ of redistilled hexane. Volatile collections begin right after the last insect infestations in multiple-species herbivory treatment. As an internal standard (IS), $1 \mu \mathrm{L}$ of 16-hexadecanolide (in distilled hexane) was added to the samples at a final concentration of $0.01 \mathrm{mg} \mathrm{mL}^{-1}$. Six plants were entrained for each treatment. Samples were stored in vials at $-20{ }^{\circ} \mathrm{C}$ until use in experiments.

\section{Gas chromatography analysis (GC)}

Volatiles were analysed on an Agilent 7890-A equipped with a flame ionization detector (FID) and a non-polar DB5MS column $(60 \mathrm{~m} \times 0.32 \mathrm{~mm}$ i.d., $0.25 \mu \mathrm{m}$ film thickness, Supelco, PA, USA). The oven temperature was maintained at $50{ }^{\circ} \mathrm{C}$ for $2 \mathrm{~min}$, programmed at $5{ }^{\circ} \mathrm{C} \mathrm{min}^{-1}$ to $180{ }^{\circ} \mathrm{C}$, held for $0.1 \mathrm{~min}$, then $10^{\circ} \mathrm{C} \mathrm{min}^{-1}$ to $250^{\circ} \mathrm{C}$, and held for $20 \mathrm{~min}$. The FID was at $270{ }^{\circ} \mathrm{C}$ and the injector at $250{ }^{\circ} \mathrm{C}$. One microlitre of each sample was injected on a splitless injector, with helium as the carrier gas. Data were collected with GC Open Lab. A generalized linear model (GLM) and Deviance analysis with gamma distribution and inverse as link function were used to compare the individual compounds from different treatments at each sampling time and the total amount of released volatiles from different treatments along the sampling times. When the analyses showed significant effects of treatments, means were compared using contrast analyses. The statistical analyses were performed using $\mathrm{R}$ 
Statistical Software (Foundation for Statistical Computing). To evaluate the influence of all compounds in separating the treatments, principal component analysis (PCA) was applied to the multivariate data. PCA was performed using a correlation matrix and comparison between groups (treatments) for each sampling time (from 24 to $96 \mathrm{~h}$ ) using Paleontological Statistics Software (PAST version 3.10).

\section{Coupled gas chromatography-mass spectrometry (GC-MS)}

Tentative identifications were performed on an Agilent 5975-MSD quadrupole mass spectrometer coupled to a GC-FID (Agilent-7890A) equipped with a DB-5MS column ( $30 \mathrm{~m} \times 0.25 \mathrm{~mm}$ i.d., $0.25 \mu \mathrm{m}$ film, Supelco, PA, USA), a splitless injector and helium as the carrier gas. Ionization was by electron impact $(70 \mathrm{eV}$, source temperature at $200{ }^{\circ} \mathrm{C}$ ). The injector was at $250{ }^{\circ} \mathrm{C}$ using the same temperature programme as in GC-FID analysis. Data were collected with ChemStation software. Tentative identifications were made by comparison of spectra with mass spectral library databases (NIST, 2008) and use of retention indices (RIs) and were confirmed by co-injection of the air entrainment sample with authentic standards. The retention indices were calculated by comparison to the retention times of a series of linear hydrocarbon alkanes $\left(\mathrm{C}_{8}-\mathrm{C}_{24}\right)$ analysed with the same separation method (Lucero et al. 2009). The identified compounds were classified as monoterpenes $[\alpha-$ pinene, camphene, $\beta$-pinene, $\beta$-myrcene, limonene, $(E)$-ocimene and linalool], homoterpenes [(E)-4,8-dimethyl-1,3,7-nonatriene (DMNT) and trimethyl-1,3,7,11-tridecatetraene (TMTT)], sesquiterpenes $[\beta$-caryophyllene, $\alpha$-humulene, $\delta$-guaiene, $\delta$-cadinene], esters [ $(Z)$-3-hexenyl acetate and methyl salicylate] and ketones [geranylacetone].

\section{Chemicals}

Hexane for HPLC ( $\geq 97 \%$ redistilled), $\alpha$-pinene (98\%), camphene $90 \%, \beta$-pinene (99\%), $\beta$-myrcene (90\%), (Z)-3-hexenyl acetate (98\%), ocimene (90\%) and methyl salicylate were purchased from Sigma-Aldrich (Steinheim, Germany). Linalool, $\alpha$-humulene (96\%), $\beta$-caryophyllene (80\%) and limonene $(97 \%)$ were purchased from TCI-America (Portland, USA). Geranylacetone (96\%) was purchased from TCI (Tokyo, Japan). DMNT and TMTT were synthesized from geraniol and $(E, E)$-farnesol, respectively (Leopold 1990).

\section{Olfactometer bioassays}

Behavioural assays were performed using Y-tube olfactometry to determine the responses of 10-day-old adult male and female $A$. grandis to volatiles collected from undamaged cotton and cotton damaged by $A$. grandis, E. heros and $S$. frugiperda, 48 and $72 \mathrm{~h}$ after initiation of herbivory. The following combinations were used: undamaged cotton volatiles (UD) versus simultaneous multiple-herbivoredamaged cotton volatiles (MHD-Sim); UD versus sequential multiple-herbivore-damaged cotton volatiles (MHD-Seq); boll weevil-damaged cotton volatiles (AGD) versus MHDSim; and AGD versus MHD-Seq. Detailed construction of the olfactometer and bioassay procedures was described by Magalhães et al. (2012). Filter papers containing $5 \mu \mathrm{L}$ of air entrainment samples (equivalent to the volatiles released by one plant in ca. $1 \mathrm{~h}$ ) were placed inside glass syringes connected to the arms of an olfactometer via silicone tubing. Charcoal-filtered, humidified air was pumped in at $0.6 \mathrm{~L} \mathrm{~min}{ }^{-1}$ and drawn out at $0.2 \mathrm{~L} \mathrm{~min}^{-1}$. Weevils were starved for $24 \mathrm{~h}$ prior to bioassays, and a single boll weevil was introduced at the base of the Y-tube olfactometer. The weevils were observed for $10 \mathrm{~min}$ and the first choice and residence time (the time spent in an arm) were noted. Each weevil was used only once, and the filter paper was replaced after five replicates. Both sexes were assayed until a total of 40 males and 40 females had responded (positive chemotaxis). After five repetitions, the Y-tube olfactometer and the side on which the treatment was presented was swapped to avoid any positional bias. Data analysis of the first choice of the boll weevil was performed by logistic regression and Wald's Chi-square test to assess significance (R Statistical Software). Residence time in treatment and control arms was analysed by paired $t$ test (R Statistical Software).

\section{Results}

\section{Air entrainment analysis}

Chemical analyses of the air entrainment samples revealed no qualitative differences among treatments over time. Compounds identified by GC-MS, using RI comparison with authentic standards, included $\alpha$-pinene $(\mathrm{RI}=938)$, camphene $(\mathrm{RI}=954), \beta$-pinene $(\mathrm{RI}=981), \beta$-myrcene $(\mathrm{RI}=990)$, $(Z)$-3-hexenyl acetate $(\mathrm{RI}=1005)$, limonene $(\mathrm{RI}=1033)$, $(E)$-ocimene $(\mathrm{RI}=1050)$, linalool $(\mathrm{RI}=1104)$, DMNT $(\mathrm{RI}=1114)$, methyl salicylate $(\mathrm{RI}=1193), \beta$-caryophyllene $(\mathrm{RI}=1424)$, geranylacetone $(\mathrm{RI}=1449), \alpha$-humulene $(\mathrm{RI}=1461), \delta$-guaiene $(\mathrm{RI}=1504), \delta$-cadinene $(\mathrm{RI}=1520)$ and TMTT $(\mathrm{RI}=1575)$. $\delta$-Guaiene and $\delta$-cadinene were tentatively identified by comparison of spectra and RIs, as no authentic standards were available. The total amount of volatile organic compounds (VOCs) produced by cotton plants differed among treatments (ANODEV $\chi^{2}=420.95, d f=5$, $P<0.001$ ), with sampling time (ANODEV $\chi^{2}=4.82, d f=3$, $P=0.03)$, and in the interaction between treatment and time (ANODEV $\chi^{2}=22.07, d f=5, P<0.001$ ). 


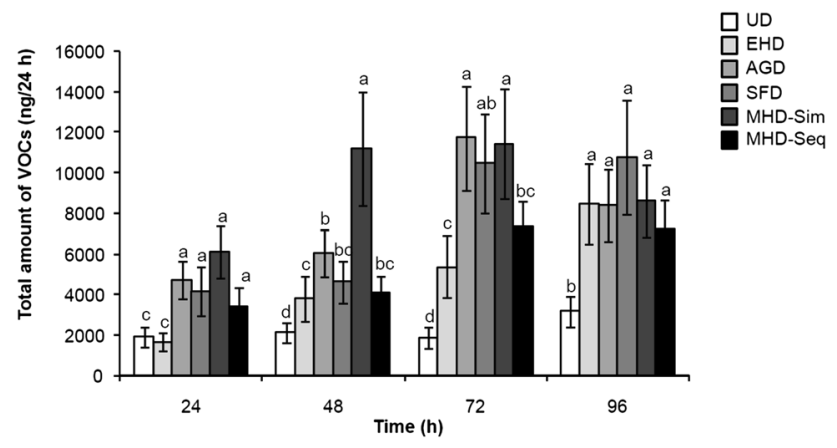

Fig. 1 Amounts (mean \pm SE) of total volatile organic compounds (VOCs) from undamaged cotton (UD), Euschistus heros-damaged cotton (EHD), Anthonomus grandis-damaged cotton (AGD), Spodoptera frugiperda-damaged cotton (SFD), simultaneous multiplespecies herbivore-damaged cotton (MHD-Sim) and sequential multiple-species herbivore-damaged cotton (MHD-Seq). In MHD-Seq, E. heros was released first; only after $72 \mathrm{~h}$ of feeding, the A. grandis and $S$. frugiperda larvae were added. The multiple-species treatments comprised the same species as from the single herbivory treatments. Means with the same letter within a given time that plants were sampled (24, 48, 72 or $96 \mathrm{~h}$ after treatment began) are not different $(P>0.05)$ by ANODEV and mean comparisons by contrast analyses
The most VOCs were released when plants were damaged by herbivores (Fig. 1). In the first $24 \mathrm{~h}$ of air entrainment, EHD plants were not induced to release volatiles, emitting the same amount as UD plants (ANODEV $\chi^{2}=181.40$, $d f=5, P>0.001)$. At $48 \mathrm{~h}$, all herbivore-damaged plants were induced, especially MHD-Sim plants, which had the highest volatile emission (ANODEV $\chi^{2}=91.94, d f=5$, $P<0.001)$. At $72 \mathrm{~h}, \mathrm{AGD}, \mathrm{SFD}$ and MHD-Sim plants released the greatest amount of total volatiles (ANODEV $\left.\chi^{2}=91.96, d f=5, P<0.001\right)$. At $96 \mathrm{~h}$, all herbivore-damaged plants produced similar amount of volatiles, and levels were still higher than in UD plants (ANODEV $\chi^{2}=91.94, d f=5$, $P<0.001$ ) (Fig. 1).

PCA showed different patterns of treatment grouping for cotton-emitted volatiles over four days of sampling (Fig. 2). At 24 h, the first two PCA components explained $50 \%$ of total variance, in which the treatment MHD-Seq was separated from the others. At $48 \mathrm{~h}$, the same components accounted for $47 \%$ of total variation, forming two distinct groups, namely MHD-Seq and MHD-Sim. The other four treatments did not differ from each other, forming an unseparated group. At $72 \mathrm{~h}$, the first two PCA components did not
Fig. 2 Principal component analysis (PCA) ordination for components 1 and 2 of volatile compounds emitted by undamaged cotton (UD), Euschistus heros-damaged cotton (EHD), Anthonomus grandis-damaged cotton (AGD), Spodoptera frugiperda-damaged cotton (SFD), simultaneous multiplespecies herbivore-damaged cotton (MHD-Sim) and sequential multiple-species herbivore-damaged cotton (MHD-Seq) over four sampling times: a $24 \mathrm{~h}, \mathbf{b}$ $48 \mathrm{~h}, \mathbf{c} 72 \mathrm{~h}$ and $\mathbf{d} 96 \mathrm{~h}$ after treatment began. The multiplespecies treatments comprised the same species from the single herbivory treatments. In each sampling time, the main compounds responsible for treatment differentiation are displayed, as well as the groups formed by different treatments (ellipse areas)

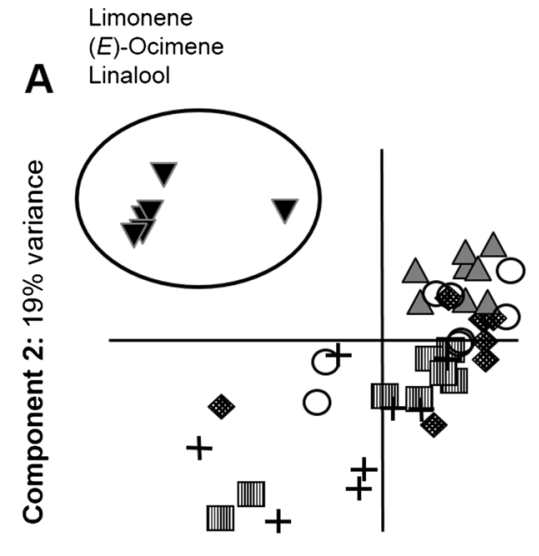

Component 1: $31 \%$ variance

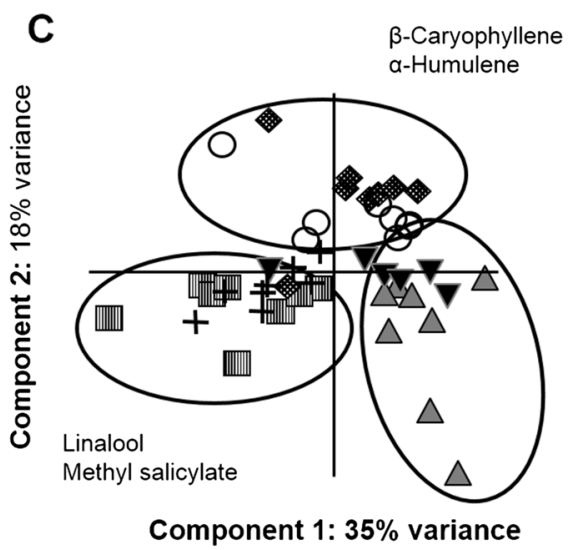

\begin{tabular}{|l}
$\mathrm{m}$ \\
$\mathrm{m} U \mathrm{UD}+\mathrm{EHD}$ AGD $\bigcirc \mathrm{SFD} \triangle \mathrm{MHD}$-Sim $\boldsymbol{\nabla}$ MHD-Seq
\end{tabular} 
explain all the variation, but they did explain approximately $53 \%$ of the total variation. At this sampling time, three different groups were formed: (i) UD + EHD, (ii) AGD + SFD and (iii) MHD-Seq + MHD-Sim (Fig. 2). Finally, at 96 h, the two components accounted for $48 \%$ of total variation, showing the herbivore-damaged treatments all together, but EHD was closer to UD plants. Differences in cotton volatiles production were observed over time, especially for the herbivore-damaged plants, as demonstrated by changes in the position of PCA scores in the coordinate axes in the diagram.

The total amount of monoterpenes was not different between UD and EHD plants, but plants submitted to these two treatments released lower amounts of monoterpenes than the other treatments (ANODEV $\chi^{2}=293.33, d f=5$, $P<0.001$ ) (Fig. 3a). UD and EHD plants emitted a mean ( \pm standard error) of $48.4 \pm 11.5$ and $71.8 \pm 17.3 \mathrm{ng} / 24 \mathrm{~h}$, respectively, of $(E)$-ocimene over four days, whereas AGD, SFD, MHD-Seq and MHD-Sim released a mean
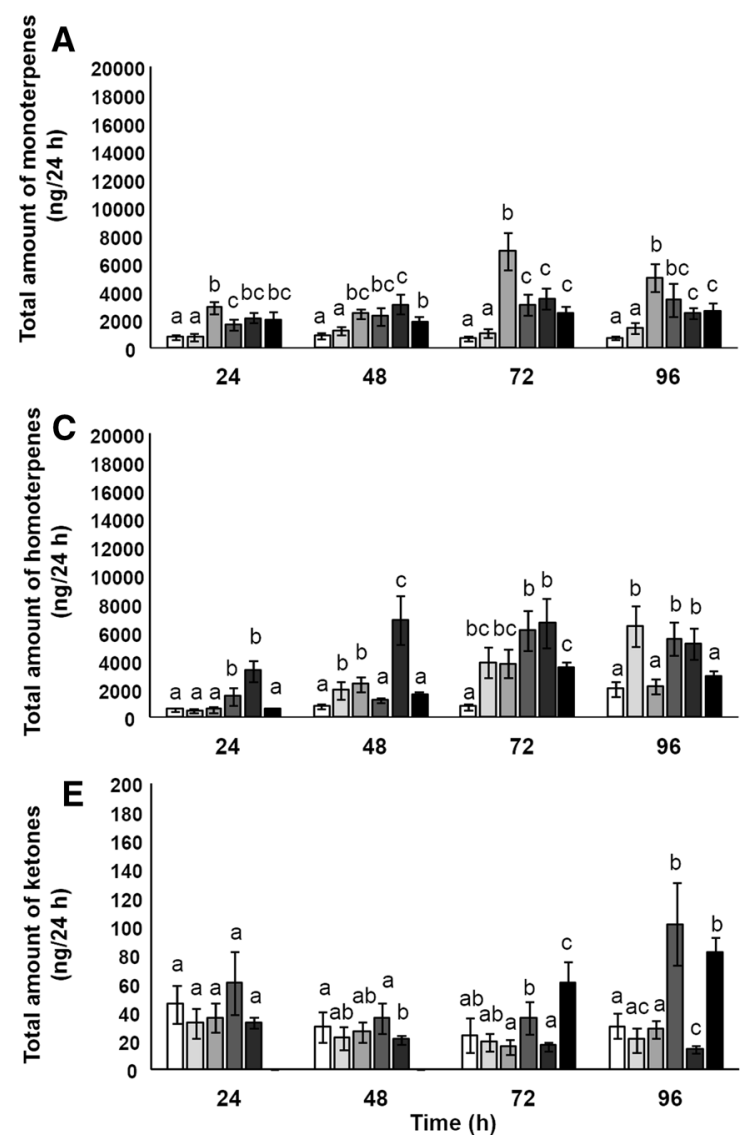

Fig. 3 Amounts (mean \pm SEM) of total monoterpenes (a), sesquiterpenes (b), homoterpenes (c), esters (d) and ketones (e) from undamaged cotton (UD), Euschistus heros-damaged cotton (EHD), Anthonomus grandis-damaged cotton (AGD), Spodoptera frugiperdadamaged cotton (SFD), simultaneous multiple-species herbivoredamaged cotton (MHD-Sim) and sequential multiple-species herbi- of $1361.2 \pm 241.7,546.5 \pm 163.1,358.1 \pm 77.4$ and $551.2 \pm 157.1 \mathrm{ng} / 24 \mathrm{~h}$, respectively (Tables $1,2,3,4$ ). The monoterpene limonene appears be related to the multipleherbivore-damaged treatments, being emitted at a mean of $145.8 \pm 15.1 \mathrm{ng} / 24 \mathrm{~h}$ by MHD-Sim and $263.8 \pm 69.6 \mathrm{ng} / 24 \mathrm{~h}$ by MHD-Seq. The other treatments released an average below $80.0 \mathrm{ng} / 24 \mathrm{~h}$, except for AGD plants, whose production increased from $72 \mathrm{~h}$ onward (Tables 1, 2, 3, 4). Linalool had similar behaviour; multiple-herbivore damage appeared to be responsible for higher emission: MHDSim and MHD-Seq released a mean of $476.0 \pm 97.7$ and $190.1 \pm 34.7 \mathrm{ng} / 24 \mathrm{~h}$, whereas the other treatments showed mean release below $50.0 \mathrm{ng} / 24 \mathrm{~h}$ (Tables $1,2,3,4$ ).

Sesquiterpene production was higher in AGD and SFD plants than other treatments (ANODEV $\chi^{2}=251, d f=5$, $P<0.001$ ) (Fig. 3b), especially for $\beta$-caryophyllene and $\alpha$-humulene. AGD and SFD released a mean of $489.7 \pm 89.2$ and $408.5 \pm 89.4 \mathrm{ng} / 24 \mathrm{~h}$ of $\beta$-caryophyllene and $215.0 \pm 50.9$ and $278.5 \pm 69.6 \mathrm{ng} / 24 \mathrm{~h}$ of $\alpha$-humulene,

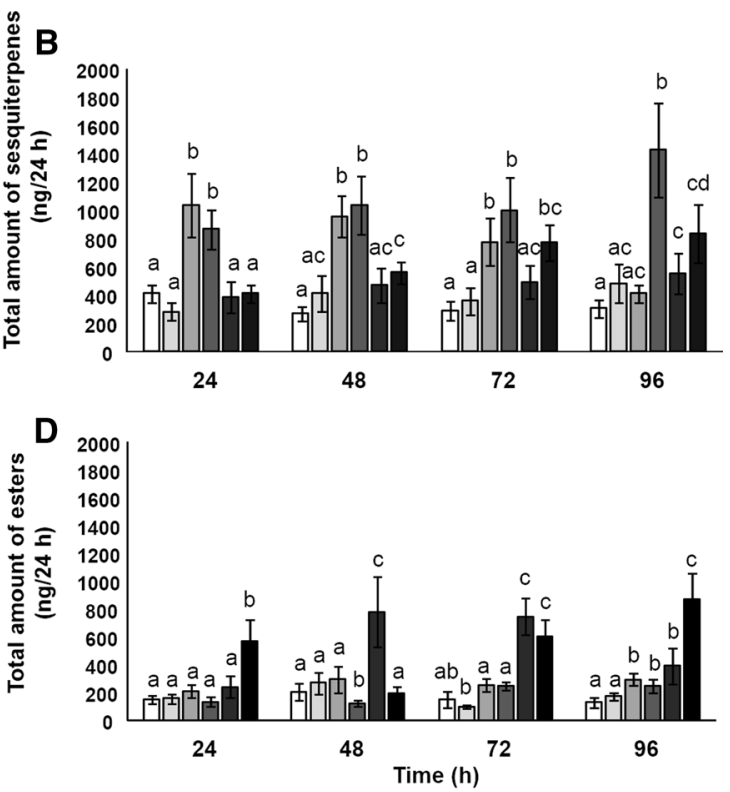

vore-damaged cotton (MHD-Seq). The multiple-species treatments comprised the same species from the single herbivory treatments. Means with the same letter within a given time that plants were sampled (24, 48, 72 or $96 \mathrm{~h}$ after treatment began) are not different $(P>0.05)$ by ANODEV and mean comparisons by contrast analyses. Note the differences in scale among the groups of compounds 
Table 1 Mean \pm SEM of total amount $(\mathrm{ng} / 24 \mathrm{~h})$ of volatiles from undamaged (UD), Euschistus heros-damaged (EHD), Anthonomus grandis-damaged (AGD), Spodoptera frugiperda-damaged (SFD), simultaneous (MHD-Sim) and sequential (MHD-Seq) multiple-species herbivore-damaged cotton at $24 \mathrm{~h}$

\begin{tabular}{|c|c|c|c|c|c|c|c|}
\hline \multirow[t]{2}{*}{ Compounds } & \multirow[t]{2}{*}{$\mathrm{RI}^{\mathrm{a}}$} & \multicolumn{6}{|l|}{ Treatments } \\
\hline & & UD & EHD & AGD & SFD & MHD-Sim & MHD-Seq \\
\hline$\alpha$-Pinene & 938 & $275.8 \pm 83.3 \mathrm{c}$ & $295.1 \pm 96.2 c$ & $1562.7 \pm 86.4 \mathrm{a}$ & $593.6 \pm 137.3 b$ & $880.7 \pm 150.3 a$ & $527.5 \pm 245.4 \mathrm{bc}$ \\
\hline Camphene & 954 & $36.8 \pm 10.1 \mathrm{a}$ & $33.6 \pm 11.1 \mathrm{a}$ & $47.8 \pm 12.4 \mathrm{a}$ & $41.4 \pm 12.6 \mathrm{a}$ & $60.5 \pm 8.6 \mathrm{a}$ & $36.0 \pm 6.0 \mathrm{a}$ \\
\hline$\beta$-Pinene & 981 & $147.3 \pm 42.1 b$ & $202.3 \pm 42.4 b$ & $461.9 \pm 94.3 \mathrm{a}$ & $305.5 \pm 76.3 \mathrm{a}$ & $250.2 \pm 25.4 \mathrm{ab}$ & $362.1 \pm 84.1 \mathrm{a}$ \\
\hline$\beta$-Myrcene & 990 & $148.4 \pm 30.2 b$ & $113.7 \pm 47.3 b$ & $350.9 \pm 128.2 \mathrm{ab}$ & $362.8 \pm 56.4 \mathrm{a}$ & $376.8 \pm 76.7 \mathrm{a}$ & $346.8 \pm 69.5 \mathrm{ab}$ \\
\hline (Z)-3-Hexenyl acetate & 1005 & $113.8 \pm 24.3 \mathrm{a}$ & $123.8 \pm 22.7 \mathrm{a}$ & $148.1 \pm 31.8 \mathrm{a}$ & $85.1 \pm 24.7 b$ & $219.4 \pm 72.5 \mathrm{a}$ & $89.1 \pm 82.5 b$ \\
\hline Limonene & 1033 & $78.0 \pm 23.6 b$ & $59.4 \pm 16.7 b$ & $80.3 \pm 19.7 b$ & $55.9 \pm 6.6 \mathrm{~b}$ & $154.6 \pm 13.6 \mathrm{a}$ & $205.6 \pm 44.8 \mathrm{a}$ \\
\hline (E)-Ocimene & 1050 & $28.9 \pm 7.8 b$ & $30.8 \pm 9.9 b$ & $332.3 \pm 80.2 \mathrm{a}$ & $245.1 \pm 93.0 \mathrm{a}$ & $247.8 \pm 31.8 \mathrm{a}$ & $420.0 \pm 151.4 \mathrm{a}$ \\
\hline Linalool & 1104 & $33.3 \pm 9.7 b$ & $25.2 \pm 7.6 b$ & $37.0 \pm 4.9 \mathrm{~b}$ & $30.5 \pm 9.1 b$ & $169.3 \pm 30.8 \mathrm{a}$ & $117.7 \pm 13.9 \mathrm{a}$ \\
\hline $\mathrm{DMNT}^{\mathrm{b}}$ & 1114 & $242.6 \pm 70.4 b$ & $128.2 \pm 76.4 \mathrm{c}$ & $235.5 \pm 78.4 b$ & $422.9 \pm 119.9 \mathrm{a}$ & $492.2 \pm 109.5 a$ & $238.2 \pm 38.4 b$ \\
\hline Methyl salicylate & 1193 & $36.8 \pm 7.5 \mathrm{a}$ & $32.5 \pm 10.9 \mathrm{a}$ & $66.2 \pm 15.4 \mathrm{a}$ & $48.8 \pm 10.4 \mathrm{a}$ & $21.2 \pm 4.6 \mathrm{a}$ & $0.0 \pm 0.0 \mathrm{~b}$ \\
\hline$\beta$-Caryophyllene & 1424 & $195.7 \pm 25.4 b$ & $202.4 \pm 39.5 b$ & $565.3 \pm 129.7 \mathrm{a}$ & $370.7 \pm 67.2 \mathrm{a}$ & $113.4 \pm 36.9 \mathrm{c}$ & $276.1 \pm 54.5 \mathrm{a}$ \\
\hline Geranylacetone & 1449 & $45.5 \pm 13.2 \mathrm{a}$ & $32.3 \pm 10.7 \mathrm{a}$ & $36.4 \pm 9.9 \mathrm{a}$ & $60.4 \pm 22.2 \mathrm{a}$ & $32.6 \pm 4.4 \mathrm{a}$ & $0.0 \pm 0.0 \mathrm{~b}$ \\
\hline$\alpha$-Humulene & 1461 & $65.9 \pm 7.9 \mathrm{c}$ & $44.1 \pm 12.7 \mathrm{c}$ & $256.3 \pm 53.0 \mathrm{a}$ & $261.7 \pm 46.1 \mathrm{a}$ & $113.9 \pm 32.0 \mathrm{~b}$ & $160.7 \pm 33.9 b$ \\
\hline$\delta$-Guaiene* & 1404 & $42.8 \pm 10.1 \mathrm{c}$ & $19.3 \pm 2.0 \mathrm{c}$ & $147.5 \pm 22.7 \mathrm{a}$ & $64.2 \pm 6.5 b$ & $116.7 \pm 29.1 \mathrm{a}$ & $0.0 \pm 0.0 \mathrm{~d}$ \\
\hline$\delta$-Cadinene* & 1520 & $104.2 \pm 20.2 \mathrm{ab}$ & $18.8 \pm 7.9 \mathrm{c}$ & $69.4 \pm 17.2 b$ & $168.4 \pm 20.2 \mathrm{a}$ & $41.8 \pm 9.3 b$ & $71.8 \pm 7.8 \mathrm{~b}$ \\
\hline TMTT $^{\mathrm{c}}$ & 1575 & $327.6 \pm 81.2 b$ & $335.1 \pm 40.0 \mathrm{~b}$ & $343.6 \pm 127.0 \mathrm{~b}$ & $1057.2 \pm 489.1 \mathrm{a}$ & $2826.8 \pm 635.1 \mathrm{a}$ & $566.8 \pm 101.6 b$ \\
\hline
\end{tabular}

Means within a row followed by the same letter are not significantly different $(P>0.05)$

The multiple-species treatments comprised of the same species from the single herbivory treatments

*Tentatively identified compound

${ }^{\text {a }}$ Retention index

${ }^{\mathrm{b}}(E)$-4,8-dimethylnona-1,3,7-triene

${ }^{\mathrm{c}}(E, E)-4,8,12$-trimethyltrideca-1,3,7,11-tetraene

respectively (Tables $1,2,3,4$ ). At $72 \mathrm{~h}$, the vectors representative of these compounds in the PCA diagram were responsible for the separation of AGD and SFD from the other treatments (Fig. 2). The total amount of homoterpenes was different among treatments (ANODEV $\chi^{2}=85.83$, $d f=5, P<0.001)$ and most herbivore-damaged treatments induced higher amounts than UD plants, mainly from $48 \mathrm{~h}$ onward (Fig. 3c). SFD (1446.5 $\pm 328.9 \mathrm{ng} / 24 \mathrm{~h})$ and MHDSim $(2159.5 \pm 437.9 \mathrm{ng} / 24 \mathrm{~h})$ emitted more DMNT than the others, which released a mean below $500.0 \mathrm{ng} / 24 \mathrm{~h}$ (Tables 1, 2, 3, 4). The multiple-herbivore-damaged plants produced higher amounts of esters with great variability over time (ANODEV $\chi^{2}=81.07, d f=5, P<0.001$ ) (Fig. 3d). In addition, in the ketone group (geranylacetone) higher emission was obtained at $96 \mathrm{~h}$ for SFD and MHDSeq (ANODEV $\chi^{2}=46.74, d f=5, P<0.001$ ) (Fig. 3e). The relative composition of volatile classes differed among treatments, but the monoterpenes and homoterpenes were the dominant groups (Fig. 4). These differences show that cotton has specific responses depending on the attacking herbivore and its interactions with other organisms.

\section{Bioassays}

Bioassays were performed using samples from air entrainment at 48 and $72 \mathrm{~h}$ because major differences in total volatile emissions between treatments were observed at these sampling times. In the Y-tube olfactometer, male A. grandis preferred VOCs released by cotton damaged by conspecifics (AGD), for either $48 \mathrm{~h}\left(\chi^{2}=7.49\right.$, $d f=1, P=0.006)$ or $72 \mathrm{~h}\left(\chi^{2}=4.69, d f=1, P=0.03\right)$, compared to VOCs from the UD control (Fig. 5a). Even when cotton was damaged by multiple species, male $A$. grandis preferred the herbivore-induced volatiles over constitutive VOCs (MHD-Sim: $48 \mathrm{~h} \chi^{2}=4.69, d f=1$, $P=0.03$ and $72 \mathrm{~h} \chi^{2}=4.69, d f=1, P=0.03$; MHD-Seq: $48 \mathrm{~h} \chi^{2}=4.69, d f=1, P=0.03$ and $72 \mathrm{~h} \chi^{2}=6.03, d f=1$, $P=0.014$ ) (Fig. 5a). Female A. grandis showed the same response pattern, preferring VOCs from AGD cotton, at both $48 \mathrm{~h}\left(\chi^{2}=4.69, d f=1, P=0.03\right)$ and $72 \mathrm{~h}\left(\chi^{2}=6.03\right.$, $d f=1, P=0.014)$ and multiple-herbivore-damaged cotton (MHD-Sim: $48 \mathrm{~h} \chi^{2}=4.70, d f=1, P=0.03$ and $72 \mathrm{~h}$ $\chi^{2}=4.69, d f=1, P=0.03$; MHD-Seq: 48 h $\chi^{2}=4.69$, 
Table 2 Mean \pm SEM of total amount $(\mathrm{ng} / 24 \mathrm{~h})$ of volatiles from undamaged (UD), Euschistus heros-damaged (EHD), Anthonomus grandis-damaged (AGD), Spodoptera frugiperda-damaged (SFD), simultaneous (MHD-Sim) and sequential (MHD-Seq) multiple-species herbivore-damaged cotton at $48 \mathrm{~h}$

\begin{tabular}{|c|c|c|c|c|c|c|c|}
\hline \multirow[t]{2}{*}{ Compounds } & \multirow[t]{2}{*}{$\mathrm{RI}^{\mathrm{a}}$} & \multicolumn{6}{|l|}{ Treatments } \\
\hline & & UD & EHD & AGD & SFD & MHD-Sim & MHD-Seq \\
\hline$\alpha$-Pinene & 938 & $359.0 \pm 97.8 b$ & $513.3 \pm 103.7 \mathrm{~b}$ & $1327.8 \pm 140.4 a$ & $957.0 \pm 331.9 \mathrm{a}$ & $1043.3 \pm 173.1 \mathrm{a}$ & $406.6 \pm 106.5 b$ \\
\hline Camphene & 954 & $43.7 \pm 9.9 b$ & $38.7 \pm 11.5 b$ & $41.5 \pm 6.7 b$ & $42.0 \pm 9.7 \mathrm{~b}$ & $65.7 \pm 12.2 \mathrm{ab}$ & $30.2 \pm 7.3 \mathrm{bc}$ \\
\hline$\beta$-Pinene & 981 & $195.8 \pm 34.6 \mathrm{a}$ & $293.2 \pm 130.0 \mathrm{a}$ & $261.2 \pm 43.3 \mathrm{a}$ & $340.1 \pm 96.9 a$ & $276.3 \pm 81.5 \mathrm{a}$ & $344.9 \pm 81.7 \mathrm{a}$ \\
\hline$\beta$-Myrcene & 990 & $135.8 \pm 24.8 \mathrm{~b}$ & $225.1 \pm 27.5 b$ & $189.0 \pm 58.3 \mathrm{~b}$ & $421.4 \pm 86.3 \mathrm{a}$ & $431.0 \pm 128.0 \mathrm{a}$ & $486.0 \pm 116.0 \mathrm{a}$ \\
\hline (Z)-3-Hexenyl acetate & 1005 & $156.1 \pm 48.8 b$ & $236.5 \pm 66.6 b$ & $269.9 \pm 93.3 b$ & $87.6 \pm 13.9 \mathrm{c}$ & $557.2 \pm 185.4 \mathrm{a}$ & $179.3 \pm 38.0 \mathrm{~b}$ \\
\hline Limonene & 1033 & $45.9 \pm 12.4 b$ & $73.7 \pm 17.2 b$ & $45.8 \pm 12.6 b$ & $54.5 \pm 9.5 b$ & $137.0 \pm 12.8 \mathrm{a}$ & $178.3 \pm 47.3 \mathrm{a}$ \\
\hline (E)-Ocimene & 1050 & $47.8 \pm 11.4 b$ & $53.6 \pm 8.1 b$ & $514.2 \pm 93.4 \mathrm{a}$ & $410.6 \pm 98.1 \mathrm{a}$ & $609.4 \pm 193.3 \mathrm{a}$ & $286.0 \pm 37.6 \mathrm{a}$ \\
\hline Linalool & 1104 & $33.8 \pm 11.9 \mathrm{c}$ & $16.8 \pm 2.6 \mathrm{c}$ & $34.6 \pm 10.4 \mathrm{c}$ & $30.6 \pm 9.3 c$ & $527.2 \pm 107.2 \mathrm{a}$ & $74.1 \pm 11.3 b$ \\
\hline $\mathrm{DMNT}^{\mathrm{b}}$ & 1114 & $282.7 \pm 56.2 \mathrm{c}$ & $321.2 \pm 108.2 \mathrm{c}$ & $293.3 \pm 83.7 \mathrm{c}$ & $469.4 \pm 88.0 \mathrm{~b}$ & $2600.9 \pm 631.0 \mathrm{a}$ & $750.2 \pm 77.2 b$ \\
\hline Methyl salicylate & 1193 & $49.9 \pm 11.2 b$ & $32.2 \pm 9.1 \mathrm{~b}$ & $24.8 \pm 5.0 \mathrm{~b}$ & $35.8 \pm 10.7 b$ & $221.8 \pm 65.7 \mathrm{a}$ & $12.6 \pm 11.7 \mathrm{c}$ \\
\hline$\beta$-Caryophyllene & 1424 & $107.5 \pm 20.2 b$ & $262.6 \pm 88.4 b$ & $556.6 \pm 85.3 \mathrm{a}$ & $446.4 \pm 70.5 a$ & $114.4 \pm 47.5 \mathrm{c}$ & $319.2 \pm 29.4 b$ \\
\hline Geranylacetone & 1449 & $30.1 \pm 10.7 \mathrm{a}$ & $21.9 \pm 7.5 \mathrm{a}$ & $26.4 \pm 6.8 \mathrm{a}$ & $35.9 \pm 10.5 a$ & $20.7 \pm 3.1 \mathrm{a}$ & $0.0 \pm 0.0 \mathrm{~b}$ \\
\hline$\alpha$-Humulene & 1461 & $36.4 \pm 7.9 b$ & $38.7 \pm 8.4 b$ & $178.7 \pm 19.3 \mathrm{a}$ & $287.4 \pm 95.5 \mathrm{a}$ & $81.2 \pm 24.2 b$ & $107.5 \pm 24.3 \mathrm{a}$ \\
\hline$\delta$-Guaiene* & 1404 & $25.4 \pm 7.9 \mathrm{c}$ & $52.9 \pm 17.2 \mathrm{a}$ & $145.9 \pm 24.1 \mathrm{a}$ & $101.0 \pm 19.9 \mathrm{a}$ & $156.1 \pm 32.1 \mathrm{a}$ & $74.9 \pm 14.7 b$ \\
\hline$\delta$-Cadinene* & 1520 & $98.8 \pm 19.3 b$ & $56.1 \pm 12.8 \mathrm{c}$ & $75.4 \pm 17.0 \mathrm{c}$ & $202.5 \pm 21.5 \mathrm{a}$ & $117.6 \pm 19.6 b$ & $56.2 \pm 11.1 \mathrm{c}$ \\
\hline TMTT $^{\mathrm{c}}$ & 1575 & $497.9 \pm 114.7 \mathrm{c}$ & $1578.0 \pm 510.9 \mathrm{~b}$ & $2085.6 \pm 432.9 \mathrm{~b}$ & $730.1 \pm 80.1 \mathrm{a}$ & $4274.9 \pm 1103.6 \mathrm{a}$ & $823.5 \pm 169.5 c$ \\
\hline
\end{tabular}

Means within a row followed by the same letter are not significantly different $(P>0.05)$

The multiple-species treatments comprised of the same species from the single herbivory treatments

*Tentatively identified compound

${ }^{\mathrm{a}}$ Retention index

${ }^{\mathrm{b}}(E)$-4,8-dimethylnona-1,3,7-triene

${ }^{\mathrm{c}}(E, E)$-4,8,12-trimethyltrideca-1,3,7,11-tetraene

$d f=1, P=0.03$ and $\left.72 \mathrm{~h} \chi^{2}=6.03, d f=1, P=0.014\right)$ over UD plants (Fig. 5b). When volatiles from MHD-Sim or MHD-Seq were compared to volatiles from AGD, at both 48 and $72 \mathrm{~h}$, female weevils did not show any preference $(P>0.05)$ (Fig. 5b).

Male and female A. grandis spent more time in the olfactometer arm containing VOCs from AGD at either $48 \mathrm{~h}$ (males $t=3.187, d f=1, P=0.002$; females $t=2.911$, $d f=1, P=0.004$ ) or $72 \mathrm{~h}$ (males $t=3.146, d f=1, P=0.002$; females $t=2.911, d f=1, P=0.004$ ) (Fig. 6). Similar results were obtained for residence time when multiple-herbivoredamaged treatments were compared to the control: male and female $A$. grandis spent more time in the arm containing VOCs of MHD-Sim at $48 \mathrm{~h}$ (males $t=2.887, d f=1$, $P=0.005$; females $t=2.105, d f=1, P=0.004)$ and $72 \mathrm{~h}$ (males $t=3.635, d f=1, P<0.01$; females $t=2.329, d f=1$, $P=0.025$ ), and MHD-Seq at $48 \mathrm{~h}$ (males $t=3.282, d f=1$, $P=0.001$; females $t=3.818, d f=1, P<0.01)$ and $72 \mathrm{~h}$ (males $t=3.146, d f=1, P=0.002$; females $t=2.255, d f=1$, $P=0.029$ ) (Fig. 6). Finally, there was no difference in the residence time when volatiles from MHD-Sim or MHD-Seq were compared to volatiles from AGD, at both 48 and $72 \mathrm{~h}$ $(P>0.05)$ (Fig. 6).

\section{Discussion}

Previously, it was demonstrated that cotton plants responded differently under single-species herbivory by $A$. grandis, $S$. frugiperda and $E$. heros and this specific response influenced boll weevil's attraction towards cotton volatiles, being attracted only when cotton was attacked by conspecifics (Magalhães et al. 2012). In this study, the emission of volatiles was evaluated in cotton plants under multiple-species herbivory (simultaneous or sequential attack) by $A$. grandis, E. heros and S. frugiperda and to single-species herbivory (A. grandis) and the boll weevil's attraction to cotton plant volatiles subjected to multi-species herbivory was also evaluated. The herbivory damage caused by multiple attackers induced the emission of 16 major volatile compounds, which were also emitted when cotton was individually damaged by each of the evaluated species (Magalhães et al. 2012). The chemical profile of volatiles obtained in simultaneous (three species placed at the same time) and sequential attack (three species placed at different moments) resulted in the same qualitative pattern. There was, however, a difference in the amount and proportion of the compounds emitted. In addition, cotton VOCs induced by A. grandis' individual attack 
Table 3 Mean \pm SEM of total amount $(\mathrm{ng} / 24 \mathrm{~h})$ of volatiles from undamaged (UD), Euschistus heros-damaged (EHD), Anthonomus grandis-damaged (AGD), Spodoptera frugiperda-damaged (SFD), simultaneous (MHD-Sim) and sequential (MHD-Seq) multiple-species herbivore-damaged cotton at $72 \mathrm{~h}$

\begin{tabular}{|c|c|c|c|c|c|c|c|}
\hline \multirow[t]{2}{*}{ Compounds } & \multirow[t]{2}{*}{$\mathrm{RI}^{\mathrm{a}}$} & \multicolumn{6}{|l|}{ Treatments } \\
\hline & & UD & EHD & AGD & SFD & MHD-Sim & MHD-Seq \\
\hline$\alpha$-Pinene & 938 & $327.2 \pm 71.8 \mathrm{~d}$ & $442.0 \pm 110.8 \mathrm{~cd}$ & $2565.9 \pm 595.4 \mathrm{a}$ & $1474.1 \pm 296.4 b$ & $1008.5 \pm 121.7 b$ & $778.7 \pm 227.0 \mathrm{c}$ \\
\hline Camphene & 954 & $30.1 \pm 7.5 b$ & $43.7 \pm 15.1 b$ & $31.9 \pm 7.8 \mathrm{~b}$ & $44.0 \pm 11.4 \mathrm{~b}$ & $193.4 \pm 88.3 \mathrm{a}$ & $44.3 \pm 16.1 b$ \\
\hline$\beta$-Pinene & 981 & $108.6 \pm 27.1 b$ & $147.5 \pm 11.2 b$ & $459.7 \pm 62.5 \mathrm{a}$ & $365.7 \pm 84.0 \mathrm{a}$ & $337.5 \pm 98.7 \mathrm{a}$ & $351.3 \pm 52.4 \mathrm{a}$ \\
\hline$\beta$-Myrcene & 990 & $68.0 \pm 18.6 \mathrm{~d}$ & $250.6 \pm 108.5 c$ & $1295.8 \pm 218.6 \mathrm{a}$ & $422.5 \pm 95.2 b$ & $377.8 \pm 72.2 b$ & $334.8 \pm 40.5 b c$ \\
\hline (Z)-3-Hexenyl acetate & 1005 & $111.6 \pm 45.4 b c$ & $70.5 \pm 9.8 \mathrm{c}$ & $221.0 \pm 37.5 b$ & $204.4 \pm 23.8 b$ & $451.2 \pm 52.6 \mathrm{a}$ & $273.6 \pm 70.4 b$ \\
\hline Limonene & 1033 & $61.6 \pm 18.9 c$ & $42.2 \pm 10.5 c$ & $196.0 \pm 44.0 \mathrm{~b}$ & $64.7 \pm 6.5 c$ & $166.0 \pm 42.5 b$ & $322.2 \pm 105.5 a$ \\
\hline (E)-Ocimene & 1050 & $67.4 \pm 13.5 \mathrm{c}$ & $90.1 \pm 24.7 \mathrm{c}$ & $2338.8 \pm 389.9 a$ & $682.4 \pm 238.2 b$ & $790.4 \pm 188.1 b$ & $325.3 \pm 67.6 b$ \\
\hline Linalool & 1104 & $26.6 \pm 7.9 b$ & $21.9 \pm 5.9 \mathrm{~b}$ & $35.2 \pm 9.2 b$ & $46.7 \pm 9.5 b$ & $624.6 \pm 114.4 \mathrm{a}$ & $263.9 \pm 55.5 a$ \\
\hline $\mathrm{DMNT}^{\mathrm{b}}$ & 1114 & $371.2 \pm 129.8 b$ & $489.9 \pm 122.9 b$ & $546.7 \pm 202.1 \mathrm{~b}$ & $2555.7 \pm 537.8 \mathrm{a}$ & $2740.2 \pm 635.2 \mathrm{a}$ & $537.3 \pm 68.4 b$ \\
\hline Methyl salicylate & 1193 & $35.8 \pm 10.5 b$ & $25.0 \pm 2.5 b$ & $32.0 \pm 8.4 \mathrm{~b}$ & $40.5 \pm 8.7 b$ & $298.3 \pm 76.0 \mathrm{a}$ & $327.4 \pm 56.9 a$ \\
\hline$\beta$-Caryophyllene & 1424 & $119.9 \pm 28.1 b$ & $199.4 \pm 56.4 b$ & $297.9 \pm 66.5 a$ & $347.6 \pm 108.4 a$ & $144.6 \pm 40.7 b$ & $311.1 \pm 47.3 \mathrm{a}$ \\
\hline Geranylacetone & 1449 & $24.0 \pm 11.8 \mathrm{a}$ & $19.1 \pm 5.9 \mathrm{a}$ & $15.6 \pm 5.5 \mathrm{a}$ & $35.8 \pm 11.2 \mathrm{a}$ & $16.4 \pm 3.1 \mathrm{a}$ & $61.2 \pm 14.4 \mathrm{a}$ \\
\hline$\alpha$-Humulene & 1461 & $50.9 \pm 15.5 b$ & $40.2 \pm 15.5 b$ & $239.7 \pm 51.6 \mathrm{a}$ & $269.7 \pm 56.2 \mathrm{a}$ & $72.5 \pm 19.3 b$ & $258.0 \pm 49.9 \mathrm{a}$ \\
\hline 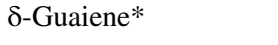 & 1404 & $36.6 \pm 11.4 b$ & $37.0 \pm 10.8 b$ & $150.4 \pm 28.9 a$ & $159.1 \pm 24.9 a$ & $124.9 \pm 37.1 \mathrm{a}$ & $123.9 \pm 26.5 \mathrm{a}$ \\
\hline$\delta$-Cadinene* & 1520 & $81.5 \pm 11.9 b$ & $82.5 \pm 14.9 b$ & $87.7 \pm 19.4 b$ & $226.9 \pm 41.0 \mathrm{a}$ & $151.7 \pm 20.1 \mathrm{a}$ & $81.2 \pm 5.2 \mathrm{~b}$ \\
\hline TMTT $^{\mathrm{c}}$ & 1575 & $376.0 \pm 87.8 b$ & $3384.6 \pm 997.5 \mathrm{a}$ & $3231.8 \pm 808.1 \mathrm{a}$ & $3543.0 \pm 859.2 \mathrm{a}$ & $3922.8 \pm 1101.3 \mathrm{a}$ & $2946.6 \pm 344.4 a$ \\
\hline
\end{tabular}

Means within a row followed by the same letter are not significantly different $(P>0.05)$

The multiple-species treatments comprised of the same species from the single herbivory treatments

*Tentatively identified compound

${ }^{\mathrm{a}}$ Retention index

${ }^{\mathrm{b}}(E)$-4,8-dimethylnona-1,3,7-triene

${ }^{\mathrm{c}}(E, E)-4,8,12$-trimethyltrideca-1,3,7,11-tetraene

were attractive to conspecifics, as were the volatiles induced by the multiple-species herbivory in both simultaneous and sequential attacks.

In agroecosystems, it is common to find crops attacked simultaneously by different herbivores, including herbivores from different food guilds (chewing or piercing-sucking, for example). This interaction between organisms with different feeding modes sharing the same resource, i.e., the plant, can lead to modifications in the composition of volatiles emitted in response to herbivory (Rodriguez-Saona et al. 2003; Pierre et al. 2011). The volatile profile induced by E. heros damage (EHD) was similar to that of control plants (UD), especially when comparing the total amount of volatile per compound classes. As observed in the PCA, EHD and UD treatments were grouped together for sampling times of 72 and $96 \mathrm{~h}$. In addition, multiple- and single-species attacks with chewing insects produced higher amounts of volatiles than single-species attack by $E$. heros. These results show that the type of injury directly affects the production of VOCs. Piercing-sucking insects tend to induce milder reactions than chewing insects, which cause more severe injuries due to the destruction of plant tissue (Turlings et al. 1998; Rodriguez-Saona et al. 2003; Delphia et al. 2007). This was also true for Nicotiana attenauata Torr. ex S. Watson (Solanales: Solanaceae) when damaged by Frankliniella occidentalis (Pegrande) (Thysanoptera: Thripidae) and Heliothis virescens (Fabricius) (Lepidoptera: Noctuidae) (Delphia et al. 2007). The induction in response to the herbivory of thrips (piercing-sucking) led to the emission of two compounds only, while multiple-species herbivory (thrips + caterpillars) promoted the release of a different qualitative and quantitative chemical profile of VOCs.

As expected, the multiple-species and single-species treatments with chewing insects emitted the highest amounts of volatiles. Even in the MHD-Seq (E. heros placed first and allowed to feed on the plant for $72 \mathrm{~h}$, followed by chewing insects, initiating the collection of volatiles), the amount of volatiles emitted was not different from that found in treatments with single $A$. grandis and $S$. frugiperda, for most sampling times. This result suggests that cotton plant response to herbivory from chewing insect is not immediate yet happens after a certain period of time, when previously induced by piercing-sucking insects (compared to MHDSim, for example). The main compound that appears to be involved in multiple-species attack is linalool. Notably, its production was not affected by single-species herbivory 
Table 4 Mean \pm SEM of total amount $(\mathrm{ng} / 24 \mathrm{~h})$ of volatiles from undamaged (UD), Euschistus heros-damaged (EHD), Anthonomus grandis-damaged (AGD), Spodoptera frugiperda-damaged (SFD), simultaneous (MHD-Sim) and sequential (MHD-Seq) multiple-species herbivore-damaged cotton at $96 \mathrm{~h}$

\begin{tabular}{|c|c|c|c|c|c|c|c|}
\hline \multirow[t]{2}{*}{ Compounds } & \multirow[t]{2}{*}{$\mathrm{RI}^{\mathrm{a}}$} & \multicolumn{6}{|l|}{ Treatments } \\
\hline & & UD & EHD & AGD & SFD & MHD-Sim & MHD-Seq \\
\hline$\alpha$-Pinene & 938 & $254.4 \pm 29.3 c$ & $444.2 \pm 138.8 \mathrm{c}$ & $1629.9 \pm 224.8 \mathrm{a}$ & $1624.6 \pm 615.3 \mathrm{ab}$ & $944.2 \pm 65.5 \mathrm{ab}$ & $587.3 \pm 91.0 \mathrm{~b}$ \\
\hline Camphene & 954 & $33.0 \pm 11.7 \mathrm{~d}$ & $38.5 \pm 7.0 \mathrm{~cd}$ & $49.7 \pm 7.6 \mathrm{bc}$ & $32.4 \pm 3.2 \mathrm{~cd}$ & $35.1 \pm 9.7 \mathrm{~cd}$ & $68.9 \pm 12.6 \mathrm{ab}$ \\
\hline$\beta$-Pinene & 981 & $161.3 \pm 14.6 \mathrm{c}$ & $268.2 \pm 84.4 b c$ & $576.5 \pm 62.6 a$ & $362.3 \pm 111.5 b$ & $189.7 \pm 18.7 b c$ & $438.3 \pm 69.5 \mathrm{ab}$ \\
\hline$\beta$-Myrcene & 990 & $68.3 \pm 14.5 b$ & $387.0 \pm 100.9 \mathrm{a}$ & $333.4 \pm 59.9 a$ & $523.5 \pm 166.4 \mathrm{a}$ & $280.1 \pm 53.4 \mathrm{a}$ & $498.4 \pm 138.0 \mathrm{a}$ \\
\hline (Z)-3-Hexenyl acetate & 1005 & $83.2 \pm 21.3 c$ & $134.2 \pm 16.4 \mathrm{bc}$ & $260.1 \pm 39.9 \mathrm{ab}$ & $205.0 \pm 41.1 b c$ & $265.8 \pm 86.9 b c$ & $306.4 \pm 106.5 b c$ \\
\hline Limonene & 1033 & $89.3 \pm 28.0 b$ & $46.7 \pm 9.7 b$ & $153.4 \pm 25.5 b$ & $144.9 \pm 39.1 b$ & $81.6 \pm 16.5 b$ & $322.1 \pm 92.0 \mathrm{a}$ \\
\hline (E)-Ocimene & 1050 & $48.9 \pm 11.6 b$ & $196.3 \pm 52.7 b$ & $2208.2 \pm 626.5 a$ & $714.9 \pm 228.0 \mathrm{a}$ & $493.0 \pm 126.1 \mathrm{a}$ & $390.8 \pm 87.3 \mathrm{a}$ \\
\hline Linalool & 1104 & $45.0 \pm 13.7 b$ & $31.3 \pm 7.9 b$ & $35.2 \pm 9.5 b$ & $43.7 \pm 9.8 b$ & $424.9 \pm 88.2 \mathrm{a}$ & $303.8 \pm 106.0 \mathrm{a}$ \\
\hline $\mathrm{DMNT}^{\mathrm{b}}$ & 1114 & $545.8 \pm 141.7 b$ & $2170.7 \pm 518.5 \mathrm{a}$ & $399.0 \pm 115.4 b$ & $2423.7 \pm 624.3 a$ & $1718.1 \pm 244.8 \mathrm{a}$ & $358.4 \pm 83.4 \mathrm{ba}$ \\
\hline Methyl salicylate & 1193 & $44.8 \pm 12.3 b$ & $38.1 \pm 8.2 b$ & $31.4 \pm 5.1 b$ & $41.2 \pm 9.3 b$ & $125.0 \pm 40.7 \mathrm{a}$ & $559.0 \pm 82.5 \mathrm{a}$ \\
\hline$\beta$-Caryophyllene & 1424 & $94.3 \pm 17.9 c$ & $259.4 \pm 91.5 b$ & $422.9 \pm 93.2 \mathrm{a}$ & $474.3 \pm 120.6 a$ & $147.5 \pm 39.6 b$ & $388.2 \pm 129.2 \mathrm{a}$ \\
\hline Geranylacetone & 1449 & $30.3 \pm 8.8 \mathrm{~b}$ & $20.8 \pm 8.2 \mathrm{a}$ & $27.9 \pm 6.3 b$ & $101.6 \pm 28.8 \mathrm{a}$ & $13.8 \pm 2.7 \mathrm{~b}$ & $82.2 \pm 10.1 \mathrm{a}$ \\
\hline$\alpha$-Humulene & 1461 & $39.5 \pm 7.6 \mathrm{c}$ & $59.6 \pm 12.2 \mathrm{c}$ & $190.4 \pm 50.2 b$ & $371.9 \pm 83.0 \mathrm{a}$ & $87.5 \pm 18.4 c$ & $248.5 \pm 37.3 \mathrm{a}$ \\
\hline ס-Guaiene* & 1404 & $18.0 \pm 6.6 b$ & $48.2 \pm 12.7 b$ & $250.6 \pm 50.1 \mathrm{a}$ & $231.6 \pm 55.6 a$ & $135.0 \pm 27.9 \mathrm{a}$ & $143.1 \pm 30.0 \mathrm{a}$ \\
\hline$\delta$-Cadinene* & 1520 & $151.5 \pm 32.6 b$ & $114.8 \pm 19.6 b$ & $89.5 \pm 19.6 c$ & $349.0 \pm 78.6 \mathrm{a}$ & $183.7 \pm 61.3 b$ & $53.6 \pm 13.0 \mathrm{c}$ \\
\hline TMTT $^{\mathrm{c}}$ & 1575 & $1463.9 \pm 389.5 c$ & $4237.7 \pm 922.4 a$ & $1779.5 \pm 377.0 \mathrm{bc}$ & $3138.6 \pm 597.1 \mathrm{a}$ & $3499.0 \pm 884.9 \mathrm{a}$ & $2511.6 \pm 328.7 \mathrm{ab}$ \\
\hline
\end{tabular}

Means within a row followed by the same letter are not significantly different $(P>0.05)$

The multiple-species treatments comprised of the same species from the single herbivory treatments

*Tentatively identified compound

${ }^{\text {a }}$ Retention index

${ }^{\mathrm{b}}(E)$-4,8-dimethylnona-1,3,7-triene

${ }^{\mathrm{c}}(E, E)-4,8,12$-trimethyltrideca-1,3,7,11-tetraene

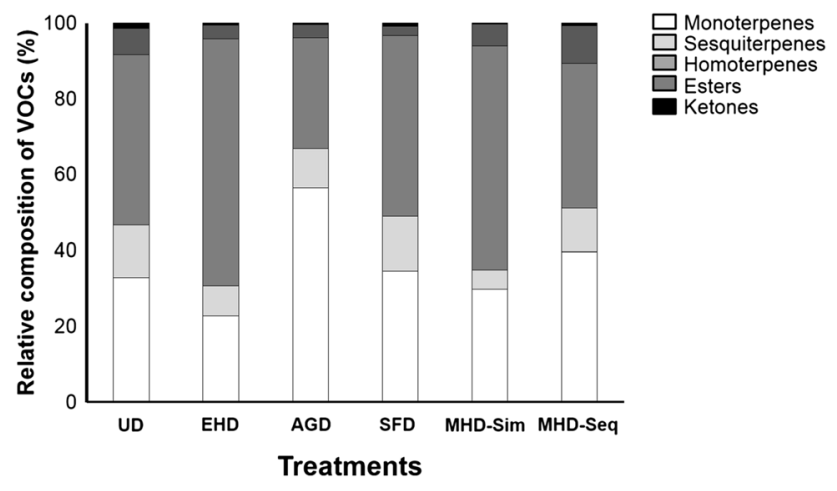

Fig. 4 Relative composition (\%) of volatile organic compounds (VOCs) classes (mean of four days) from undamaged cotton (UD), Euschistus heros-damaged cotton (EHD), Anthonomus grandis-damaged cotton (AGD), Spodoptera frugiperda-damaged cotton (SFD), simultaneous multiple-species herbivore-damaged cotton (MHD-Sim) and sequential multiple-species herbivore-damaged cotton (MHDSeq). The multiple-species treatments comprised the same species from the single herbivory treatments. The assessed classes were monoterpenes, sesquiterpenes, homoterpenes, esters and ketones compared to the control. However, the emission of both limonene and linalool was higher in the multiple-species treatment than the sum of the tree single-species treatment together. Their increase suggests that the induction of these two compounds had a synergistic effect in response to multiple-species herbivory. On the other hand, the emission of $(E)$-ocimene decreased in comparison to A. grandis damage (AGD), resulting in a metabolic volatile profile different from the other treatments in terms of proportion. Linalool and $(E)$-ocimene are biosynthesized de novo in response to insect damage and have an important role in the attraction of natural enemies of Lepidoptera pests (Paré and Tumlinson 1997; Röse et al. 1998; Röse and Tumlinson 2005); meanwhile, limonene, along with other compounds, has been described as attractive to the boll weevil (Minyard et al. 1969).

It is well known that chewing insects tend to induce the JA pathway, while piercing-sucking herbivores induce the SA pathway (Bostock et al. 2001). Thus, specificity in plant response is an important adaptive strategy because throughout its life cycle, plants are subject to attack by multiple herbivores. Such attacks can provide a metabolic crosstalk, in which the induction of one pathway can act 


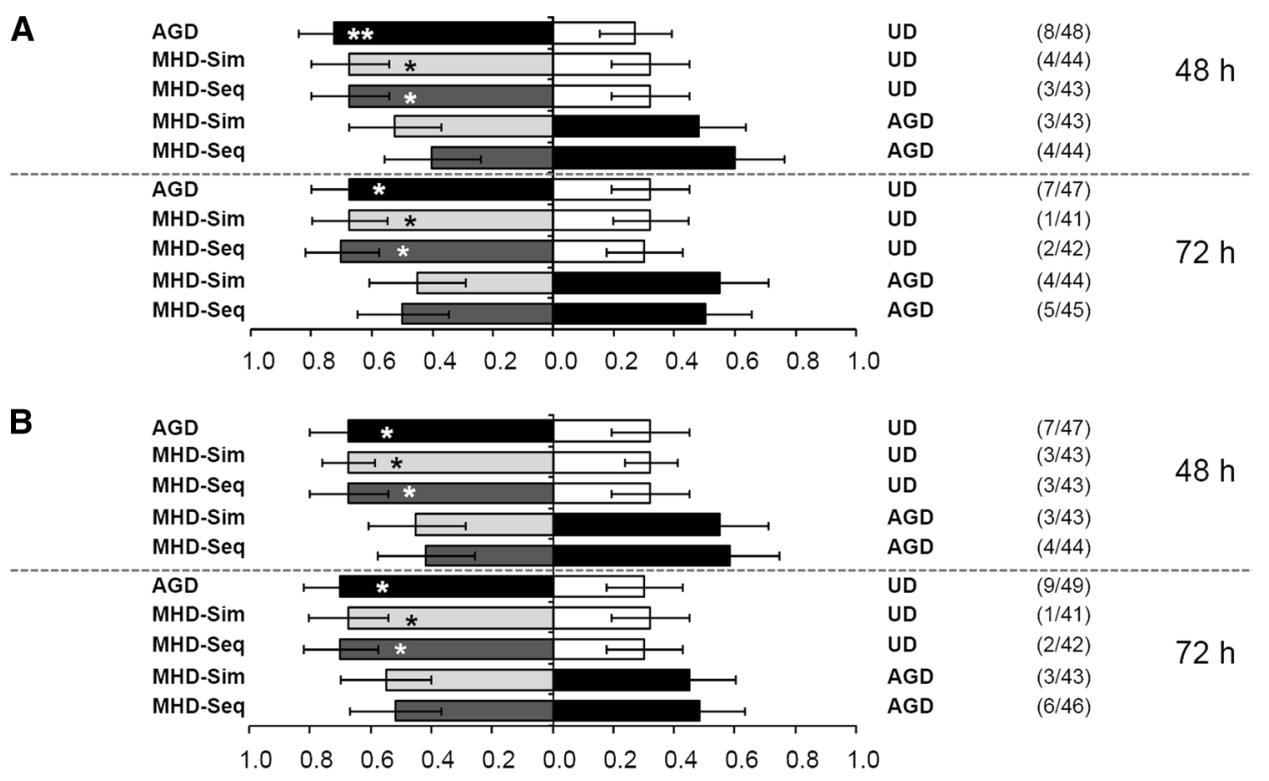

Proportion of Anthonomus grandis response

Fig. 5 First choice of male (a) and female (b) Anthonomus grandis in a Y-tube olfactometer to cotton submitted to different damage treatments 48 and $72 \mathrm{~h}$ after treatment began. UD undamaged cotton, AGDA. grandis-damaged cotton, MHD-Sim simultaneous multiplespecies herbivore-damaged cotton, $M H D$-Seq sequential multiplespecies herbivore-damaged cotton. Multiple-species treatments were comprised of Euschistus heros, A. grandis and Spodoptera frugiperda. Asterisks indicate significant differences $(* 0.05>P>0.01$ and $* * 0.01>P>0.001)$ between pairs of treatments. Bars indicate 95\% confidence intervals. Numbers in parentheses indicate A. grandis that did not respond to both treatments, and the number of bioassays
Fig. 6 Residence time in seconds of male (a) and female (b) Anthonomus grandis in a Y-tube olfactometer to cotton submitted to different damage treatments 48 and $72 \mathrm{~h}$ after treatment was started. UD undamaged cotton, AGD A. grandis-damaged cotton, $M H D$-Sim simultaneous multiple-species herbivoredamaged cotton, $M H D$ Seq sequential multiple-species herbivore-damaged cotton. Multiple-species treatments were comprised of Euschistus heros, A. grandis and Spodoptera frugiperda. Asterisks indicate significant differences $(* 0.05>P>0.01$ and $* * 0.01>P>0.001)$ between pairs of treatments. Bars indicate standard error

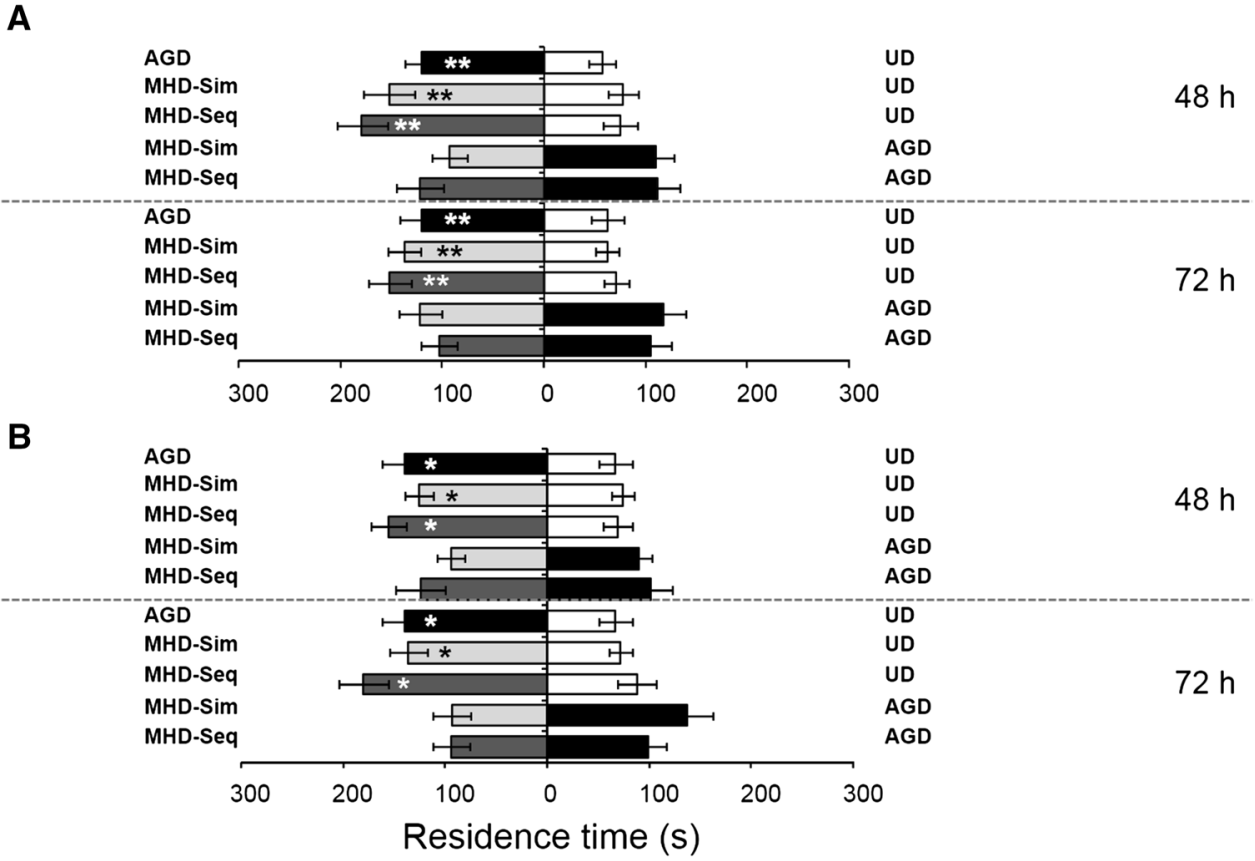

antagonistically or synergistically on the other (Schenk et al. 2000; van Wees et al. 2000; Thaler et al. 2002). However, this is an oversimplified view of crosstalk since other phytohormones such as ethylene can influence the function of this mechanism (Thaler et al. 2012). Moreover, the interaction between piercing-sucking and chewing organisms in multiple-species treatments did not cause a reduction in the total amount of volatiles emitted, as previously observed 
in cotton that suffered the simultaneous attack of Bemisia tabaci Gennadius (Hemiptera: Aleyrodidae) and the caterpillar Spodoptera exigua Hubner (Lepidopera: Noctuidae) (Rodriguez-Saona et al. 2003).

In this study, herbivory from piercing-sucking and chewing insects in cotton plants induced the same classes of volatiles, most related to the JA pathway; only methyl salicylate was related to the SA pathway. Thus, the endogenous amount of JA may be greater than that of SA, even in treatments with damage due to E. heros. It would be interesting to measure the endogenous levels of JA and SA in plants subjected to the different treatments, because these phytohormones can synergistically or antagonistically affect the biosynthesis of defensive compounds, leading to changes in herbivore-induced volatiles. In Phaseolus lunatus L. (Fabales: Fabaceae) the joined herbivory of the spider mite Tetranychus urticae Koch (Trombidiformes: Tetranychidae) and the caterpillar S. exigua also had a synergistic effect on the production of volatiles, but when Cucumis sativus $\mathrm{L}$. (Curcubitales: Curcubitaceae) was attacked by the same pair of herbivores, the emission of two compounds was reduced compared to the single-species treatments, suggesting an antagonistic effect on induction (De Boer et al. 2008).

The changes observed in compound production in this study do not appear to be relevant for A. grandis, as it was attracted both to AGD and multiple-herbivore damage plants. In all bioassays, first choice responses coincided with residence time responses showing that the weevils besides being attracted were also retained in treated areas. When volatiles from AGD plants and multiple-herbivore-damaged plants were compared, the weevils had no preference. In a previous study, the boll weevil did not respond (positive chemotaxis) to volatiles from cotton plants herbivory damaged by E. heros or S. frugiperda, (Magalhães et al. 2012). However, volatiles induced by conspecifics were highly attractive and were preferred over constitutive cotton volatiles (Magalhães et al. 2012; Silva et al. 2015). Therefore, A. grandis appears to recognize the presence of conspecifics and heterospecifics in the plant, and this configuration is important for regulating its attraction. The positive response of $A$. grandis to treatments with multiple species presupposes that the presence of conspecifics provides relevant information for its attraction, since in the single herbivory treatments with heterospecifics the boll weevil was not attracted. The qualitative similarity between the volatile profiles in the different treatments suggests that the proportion and quantity of the HIPVs could be crucial to the boll weevil to recognize the attack configuration in cotton plants.

The emission of plant herbivore-induced volatiles can be used as an olfactory cue to locate host plants with shorter search times and, consequently, lower energy costs (Kalberer et al. 2001; Stamps and Krishnan 2005). Insects that can recognize and discriminate plants infested by conspecifics may improve their fitness by locating sexual partners and oviposition sites more efficiently (Loughrin et al. 1996). Moreover, from the interpretation of these chemical tracks, induced volatiles can alter the recruitment of new herbivores by providing information on the intensity of herbivory on the host (Bernasconi et al. 1998). However, especially for herbivores with ephemeral hosts, odours that are more detectable can be prioritized over food quality (Stamps and Krishnan 2005). It is important to emphasize, however, that the primacy shown to conspecific and conspecific + heterospecific herbivore-induced volatiles by $A$. grandis may simply be a mechanism for host location, meaning that the weevils do not necessarily feed on host tissues of damaged plants. Long-distance orientation for host location is primarily related to olfactory sensory stimuli; no contact is required. To establish a feeding site, other stimuli are necessary (e.g., gustatory and tactile) to evaluate the nutritional quality of the plant (Schoonhoven et al. 2005). In addition to the effect on herbivores, HIPVs can be used as foraging cues for other insects, including natural enemies. The influence of volatiles emitted in response to single- and multiple-species attack on natural enemies' behaviour was not evaluated. However, there are examples in the literature that show that multiplespecies attack directly affects the behaviour of these organisms (Dicke et al. 2009; de Rijk et al. 2013; Chabaane et al. 2015; Ponzio et al. 2016).

The effect of coevolution processes on insects and plants is an arms race between the two groups. Plants use herbivore-induced volatiles as a defence mechanism. Thus, being attracted by a host induced to release such substances implies meeting a source of possible competitors and a high risk of influx of natural enemies (Heil 2008). Consequently, it is difficult to predict the behaviour of insects related to VOCs and HIPVs emitted by plants. Insect biology itself determines when it will be attracted or avoid herbivore-induced volatiles. For the boll weevil, behavioural aspects such as the gregarious habit may influence its final choice. This gregarious behaviour can be explained by the production of the aggregation pheromone, which attracts both males and females (Tumlinson et al. 1969). However, in addition to the aggregation pheromone, HIPVs may also have an aggregation function, as observed for Popilia japonica Newman (Coleoptera: Sacarabaeidae) (Loughrin et al. 1995). Thus, cues indicative of the presence of conspecifics increase the probability of finding sexual partners and feeding and oviposition sites.

Different patterns of plant response (emission of different amounts and proportions of compounds) to each herbivore treatment indicate that plants can distinguish aggressors and respond in a specific way for each situation (Heil 2008). Therefore, the response of plants to a single-species attack may not reflect how they will behave under the attack of multiple insects (Dicke et al. 2009). Studies that consider 
greater complexity in the interactions between multiple arthropods associated with a certain plant, as well as studies involving single- versus multiple-species attack, are important for understanding the evolution of the mechanisms of induced defence and multitrophic interactions among insects and plants because they provide important information for the development of tools for integrated pest management (IPM) strategy. A key issue for the understanding of insect and plant interactions mediated by VOCs is to determine which are the biologically relevant compounds for host plant location, within a complex blend of volatiles. Finding the active compounds is an extremely important step for the use of plant VOCs in IPM strategies (Collatz and Dorn 2013). We are currently working on the identification of the compounds responsible for boll weevil's attraction towards cotton HIPVs for the development of alternative methods for semiochemical-based weevil management, e.g., enrichment of aggregation pheromone traps with plant volatiles and/or push-pull strategy (Lamy et al. 2017).

\section{Author contributions}

DMM, MCBM, MB and RAL conceived the ideas and designed methodology; DMM and MCBM collected the data; DMM and MCBM analysed the data; DMM and MCBM led writing of the manuscript. All authors contributed critically to the drafts and gave final approval for publication.

Acknowledgements We thank Hélio Moreira dos Santos for help with laboratory rearing of weevils, Dr. Fábio Aquino de Albuquerque for providing cottonseeds and Dr. Michael A. Birkett for synthesizing the homoterpenes. We also thank the Post-Graduate Zoology Program of the University of Brasília (UnB) for use of their facility. This work received financial support from the Coordination of Superior Level Staff Improving (CAPES) through a grant to DMM (No. 99999.014964/2013-09), National Counsel of Technological and Scientific Development (CNPq), Federal District Research Foundation (FAP-DF) and the Brazilian Corporation of Agricultural Research (EMBRAPA). We state that our work conforms to the legal requirements for animal welfare in Brazil.

\section{Compliance with ethical standards}

Conflict of interest The authors declare that they have no conflicts of interest.

\section{References}

Addesso KM, McAuslane HJ, Alborn HT (2011) Attraction of pepper weevil to volatiles from damaged pepper plants. Entomol Exp Appl 138:1-11

Arimura G, Matsui K, Takabayashi J (2009) Chemical and molecular ecology of herbivore-induced plant volatiles: proximate factors and their ultimate functions. Plant Cell Physiol 50:911-923
Bernasconi ML, Turlings TCJ, Ambrosetti L, Bassetti P, Dorn S (1998) Herbivore-induced emissions of maize volatiles repel the corn leaf aphid, Rhopalosiphum maidis. Entomol Exp Appl 87:133-142

Bostock RM, Karban R, Thaler JS, Weyman PD, Gilchrist D (2001) Signal interactions in induced resistance to pathogens and insect herbivores. Eur J Plant Pathol 107:103-111

Bruinsma M, Dicke M (2008) Herbivore-induced indirect defence: from induction mechanisms to community ecology. In: Schaller A (ed) Induced plant resistance to herbivory. Springer, Berlin, pp 31-60

Chabaane Y, Laplanche D, Turlings TCJ, Desurmont GA (2015) Impact of exotic insect herbivores on native tritrophic interactions: a case study of the African cotton leafworm, Spodoptera littoralis and insects associated with the field mustard Brassica rapa. J Ecol 103:109-117

Collatz J, Dorn S (2013) A host-plant-derived volatile blend to attract the apple blossom weevil Anthonomus pomorum-the essential volatiles include a repellent constituent. Pest Manag Sci 69:1092-1098

de Boer JG, Hordijk C, Posthumus MA, Dicke M (2008) Prey and nonprey arthropods sharing a host plant: effects on induced volatile emission and predator attraction. J Chem Ecol 34:281-290

de Moraes CM, Lewis WJ, Paré PW, Alborn HT, Tumlinson JH (1998) Herbivore-infested plants selectively attract parasitoids. Nature 393:570-573

de Rijk M, Dicke M, Poelman EH (2013) Foraging behaviour by parasitoids in multiherbivore communities. Anim Behav 85:1517-1528

Delphia CM, Mescher MC, de Moraes CM (2007) Induction of plant volatiles by herbivores with different feeding habits and the effects of induced defenses on host-plant selection by thrips. J Chem Ecol 33:997-1012

Dicke M (1995) Why do plants "talk"? Chemoecol 5/6:159-165

Dicke M, van Loon JJ, Soler R (2009) Chemical complexity of volatiles from plants induced by multiple attack. Nat Chem Biol 5:317-324

Dudareva N, Negre F, Nadegowda DA, Orlava I (2006) Plant volatiles: recent advances and future perspectives. Cr Rev Plant Sci $25: 417-440$

Heil M (2008) Indirect defense via tritrophic interactions. New Phytol 178:41-61

Kalberer NM, Turlings TCJ, Rahier M (2001) Attraction of leaf beetle (Oreina cacaliae) to damaged host plants. J Chem Ecol 27:647-661

Lamy FC, Poinsot D, Cortesero AM, Dugravot S (2017) Artificially applied plant volatile organic compounds modify the behaviour of a pest with no adverse effect on its natural enemies in the field. J Pest Sci 90:611-621

Leopold EJ (1990) Selective hydroboration of a 1, 3, 7-triene: homogeraniol. Org Synth 64:164-171

Loughrin JH, Manukian A, Heath RR, Tumlinson JH (1995) Volatiles emitted by different cotton varieties damaged by feeding beet armyworm larvae. J Chem Ecol 21:1217-1222

Loughrin JH, Potter DA, Hamilton-Kemp TR, Byers ME (1996) Role of feeding-induced plant volatiles in aggregative behavior of the Japanese beetle (Coleoptera: Scarabaeidae). Environ Entomol 25:1188-1191

Lucero M, Estell R, Tellez M, Fredrickson E (2009) A retention index calculator simplifies identification of plant volatile organic compounds. Phytochem Anal 20:378-384

Magalhães DM, Borges M, Laumann RA, Sujii ER, Mayor P, Caulfield JC, Midega CA, Khan ZR, Pickett JA, Birkett MA, Blassioli-Moraes MC (2012) Semiochemicals from herbivory induced cotton plants enhance the foraging behaviour of the cotton boll weevil, Anthonomus grandis. J Chem Ecol 38:1528-1538

Michereff MFF, Borges M, Laumann RA, Diniz IR, BlassioliMoraes MC (2013) Influence of volatile compounds from 
herbivore-damaged soybean plants on searching behavior of the egg parasitoid Telenomus podisi. Entomol Exp Appl 147:9-17

Minyard JP, Hardee DD, Gueldner RC, Thompson AC, Wiygul G, Hedin PA (1969) Constituents of the cotton bud: compounds attractive to the boll weevil. J Agric Food Chem 17:1093-1097

Moraes MCB, Laumann RA, Aquino MFS, Paula DP, Borges M (2011) Effect of Bt genetic engineering on indirect defense in cotton via a tritrophic interaction. Transgenic Res 20:99-107

Paré PW, Tumlinson JH (1997) De novo biosynthesis of volatiles induced by insect herbivory in cotton plants. Plant Physiol 114:1161-1167

Pierre PS, Jansen JJ, Hordijk CA, van Dam NM, Cortesero AM, Dugravot S (2011) Differences in volatile profiles of turnip plants subjected to single and dual herbivory above- and below ground. $\mathrm{J}$ Chem Ecol 37:368-377

Poelman EH, Broekgaarden C, van Loon JJ, Dicke M (2008) Early season herbivore differentially affects plant defence responses to subsequently colonizing herbivores and their abundance in the field. Mol Ecol 17:3352-3365

Ponzio C, Gols R, Pieterse CMJ, Dicke M (2013) Ecological and phytohormonal aspects of plant volatile emission in response to single and dual infestation with herbivores and phytopathogens. Funct Ecol 27:587-598

Ponzio C, Cascone P, Cusumano A, Weldegergis BT, Fatouros NE, Guerrieri E, Dicke M, Gols R (2016) Volatile-mediated foraging behaviour of three parasitoid species under conditions of dual insect herbivore attack. Anim Behav 111:197-206

Rasmann S, Turlings TCJ (2007) Simultaneous feeding by aboveground and belowground herbivores affects the plant-mediated attraction of their respective natural enemies. Ecol Lett 10:926-936

Rodriguez-Saona C, Crafts-Brandner SJ, Cañas LA (2003) Volatile emissions triggered by multiple herbivore damage: beet armyworm and whitefly feeding on cotton plants. J Chem Ecol 29:2539-2550

Röse URS, Tumlinson JH (2005) Systemic induction of volatile release in cotton: How specific is the signal to herbivory? Planta 222:237-335

Röse URS, Manukian A, Heath RR, Tumlinson JH (1996) Volatile semiochemicals released from undamaged cotton leaves (a systemic response of living plants to caterpillar damage). Plant Physiol 111:487-495

Röse URS, Lewis WJ, Tumlinson JH (1998) Specificity of sistemically released cotton volatiles as attractants for specialist and generalist parasitic wasps. J Chem Ecol 24:303-319

Sappington TW, Spurgeon DW (2000) Preferred technique for adult sex determination of the boll weevil (Coleoptera: Curculionidae). Ann Entomol Soc Am 93:610-615

Schenk PM, Kazan K, Wilson I, Anderson JP, Richmond T, Somerville SC, Manners JM (2000) Coordinated plant defense responses in Arabidopsis revealed by microarray analysis. PNAS 97:11655-11660
Schmidt FGV, Monnerat R, Borges M, Carvalho R (2001) Criação de insetos para avaliação de agentes entomopatogênicos e semioquímicos. Embrapa Recursos Genéticos e Biotecnologia, Brasília, pp 1-20 (Circular Técnica, 11)

Schoonhoven LM, van Loon JJA, Dicke M (2005) Plant chemistry: endless variety. In: Schoonhoven M, van Loon JJA, Dicke M (eds) Insect- plant biology. Oxford University Press, Canada, pp 48-86

Silva CC, Laumann RA, Blassioli-Moraes MC, Pareja M, Borges M (2008) Euschistus heros mass rearing technique for the multiplication of Telenomus podisi. Pesq Agr Bras 43:575-580

Silva JB, Silva-Torres CSA, Blassioli-Moraes MC, Torres JB, Laumann RA, Borges M (2015) Interaction of Anthonomus grandis and cotton genotypes: biological and behavioral responses. Entomol Exp App 156:238-253

Soler R, Badenes-Pérez FR, Broekgaarden C, Zheng SJ, David A, Boland W, Dicke M (2012) Plant-mediated facilitation between a leaf-feeding and a phloem-feeding insect in a brassicaceous plant: from insect performance to gene transcription. Funct Ecol 26:156-166

Stam JM, Kroes A, Li Y, Gols R, van Loon JJA, Poelman EH, Dicke M (2014) Plant interactions with multiple insect herbivores: from community to genes. Ann Rev Plant Biol 65:689-713

Stamps J, Krishnan VV (2005) Nonintuitive cue use in habitat selection. Ecology 86:2860-2867

Szendrei Z, Malo E, Stelinski L, Rodriguez-Saona C (2009) Response of cranberry weevil (Coleoptera: Curculionidae) to host plant volatiles. Entomol Soc Am 38:861-869

Thaler JS, Fidantsef AL, Bostock RM (2002) Antagonism between jasmonate- and salicylate-mediated induced plant resistance: Effects of concentration and timing of elicitation on defense-related proteins, herbivore, and pathogen performance in tomato. J Chem Ecol 28:1143-1171

Thaler JS, Humphrey PT, Whiteman NK (2012) Evolution of jasmonate and salicylate signal crosstalk. Trends Plant Sci 17:260-270

Tumlinson JH, Hardee DD, Gueldner RC, Thompson AC, Hedin PA, Minyard JP (1969) Sex pheromone produced by the male boll weevil: isolation, identification, and synthesis. Science 166:1010-1012

Turlings TCJ, Tumlinson JH (1992) Systemic chemical signaling by herbivore-injured corn. PNAS 89:8399-8402

Turlings TCJ, Tumlinson JH, Lewis WJ (1990) Exploitation of herbivore- induced plant odors by host seeking parasitic wasps. Science 250:1251-1253

Turlings TCJ, Bernasconi M, Bertossa R, Bigler F, Caloz G, Dorn $S$ (1998) The induction of volatile emissions in maize by three herbivore species with different feeding habits: possible consequences for their natural enemies. Biol Control 11:122-129

van Wees SCM, de Swart EAM, van Pelt JA, van Loon LC, Pieterse CMJ (2000) Enhancement of induced disease resistance by simultaneous activation of salicylate- and jasmonate-dependent defense pathways in Arabidopsis thaliana. PNAS 97:8711-8716 